\title{
BRYOZOAN FAUNA FROM THE OOLITIC LIMESTONE FROM PAJAREJOS, SW SPAIN
}

\author{
Andrej ERNSTI and Sergio RODRÍGUEZ² \\ ${ }^{1}$ Institut für Geowissenschaften der Christian-Albrechts-Universität zu Kiel, \\ Ludewig-Meyn-Str. 10, D-24118 Kiel, Germany \\ ${ }^{2}$ UEI-Departamento de Paleontología (CSIC-UCM), Facultad de Ciencias \\ Geológicas, Universidad Complutense, Ciudad Universitaria s/n, 20816 Madrid, \\ Spain
}

Ernst, A. \& Rodríguez, S. 2010. Bryozoan fauna from the oolitic limestone from Pajarejos, SW Spain. [Asociaciones de briozoos de las calizas oolíticas de Pajarejos, suroeste de España.] Revista Española de Paleontología, 25 (2), 83-88, ISSN 0213-6937

\begin{abstract}
Outcrops of Devonian rocks at the hill of Pajarejos near Campillo de Llerena, south-western Spain, expose oolitic limestone which contains abundant fragments of bryozoans, whereas other macrofauna is scarce. Eight bryozoan species were identified, which date the outcrop as Middle Devonian. The assemblage shows close affinities with that described from Sabkhat Lafayrina reef complex in Western Sahara, which is situated more than 1,000 km further south today. The studied association supports the previously proposed hypothesis that South-western Spain belonged to the northern margin of Gondwana during the Middle Devonian.
\end{abstract}

Keywords: Bryozoans, Middle Devonian, Ossa-Morena, SW Spain, Paleogeography.

\section{RESUMEN}

Los afloramientos de calizas del Devónico en la loma de Pajarejos, cerca de Campillo de Llerena, suroeste de España, muestran calizas oolíticas que contienen abundantes fragmentos de briozoos, en tanto que otros tipos de macrofauna son escasos o ausentes. Se han identificado ocho especies de briozoos que permiten datar el afloramiento como Devónico Medio. La asociación muestra importantes afinidades con la descrita en el complejo arrecifal de Sabkhat Lafayrina en el Sahara Occidental, situado hoy día a más de $1.000 \mathrm{~km}$ al sur del afloramiento estudiado. La asociación estudiada apoya la hipótesis, ampliamente propuesta previamente, de que la región de Ossa-Morena pertenecería al margen septentrional de Gondwana durante el Devónico Medio.

Palabras clave: Briozoos, Devónico Medio, Ossa-Morena, SO de España, Paleogeografía.

\section{INTRODUCTION}

Devonian rocks at the Sierra Morena in southwestern Spain, form a $200 \mathrm{~km}$ long outcrop from Cáceres in the northwest to Córdoba in the southeast, near the Guadalquivir Valley (Fig. 1). They cover part of the Obejo-Valsequillo-Puebla de la Reina Domain that is located in the controversial area of contact between the Ossa-Morena and Centro-Iberian zones (Julivert et al., 1974; Dallmeyer \& Martínez-García, 1990; Quesada, 2006; Ribeiro et al., 2007). A succession of shales, red sandstones and limestones crop out in the vicinity of Campillo de Llerena, in the western border of this domain. These outcrops belong to a synclinorium that was dated as Frasnian to Visean by Sánchez-Cela \& Gabaldón (1977), who found Devonian brachiopods in the basal red sandstones and recorded Carboniferous foraminifera in limestone beds. The limestone beds occur in two bands that crop out along a small, NW-SE oriented valley. Most outcrops are small and mainly expose only a few metres of well bedded limestones and marls. However, Rodríguez (1978) described some outcrops at the hill of Pajarejos, close to the hermitage of San Antonio, in the left fork of the Andihuela stream, $1.5 \mathrm{~km}$ northwest of Campillo de Llerena (Fig. 1) in which the succession comprises 16.5 metres of massive limestones, sandy limestones and marls (Fig. 2). The most conspicuous feature of the limestones is the absence of macrofauna except bryozoans, which 


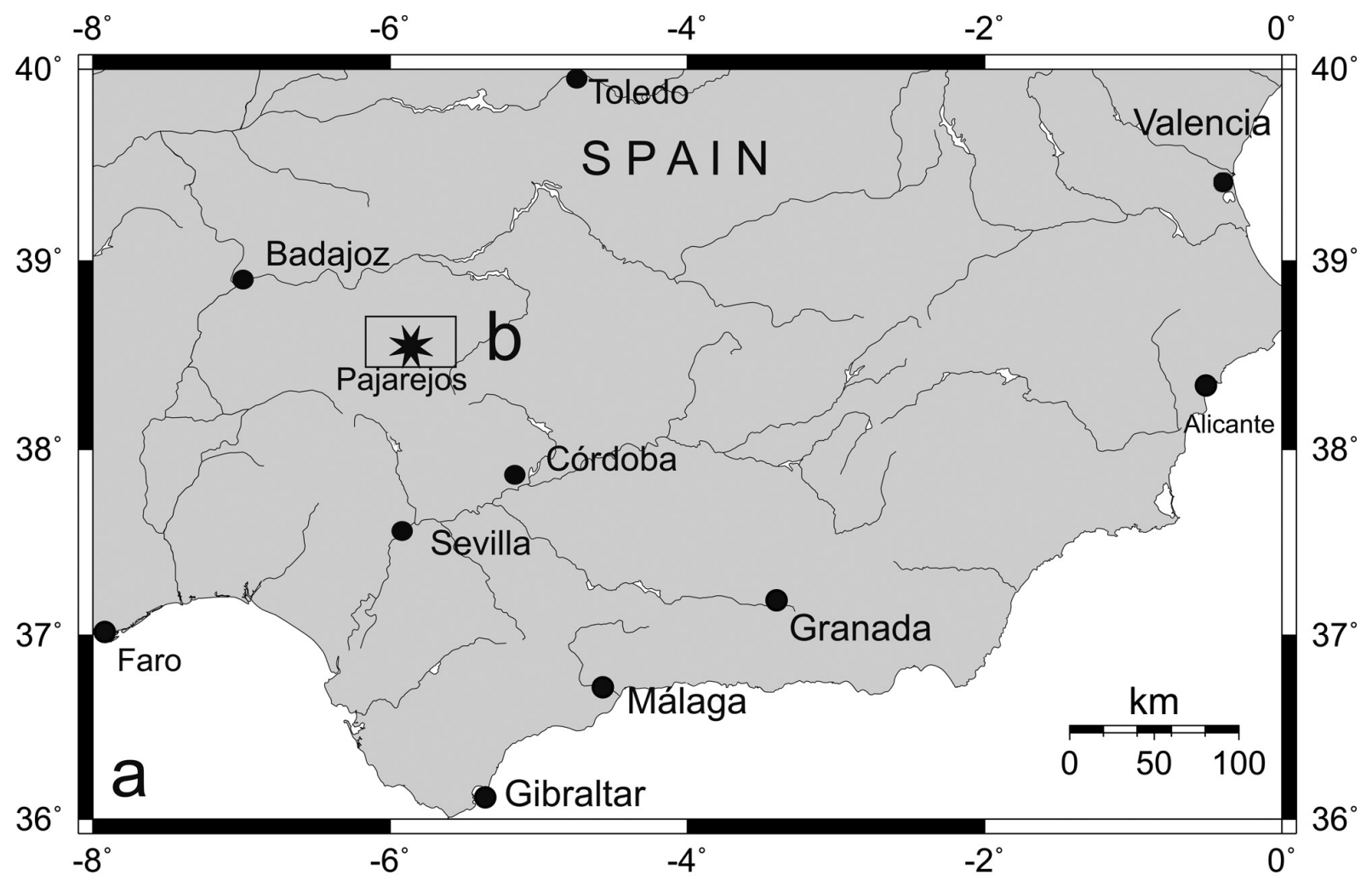

* working area

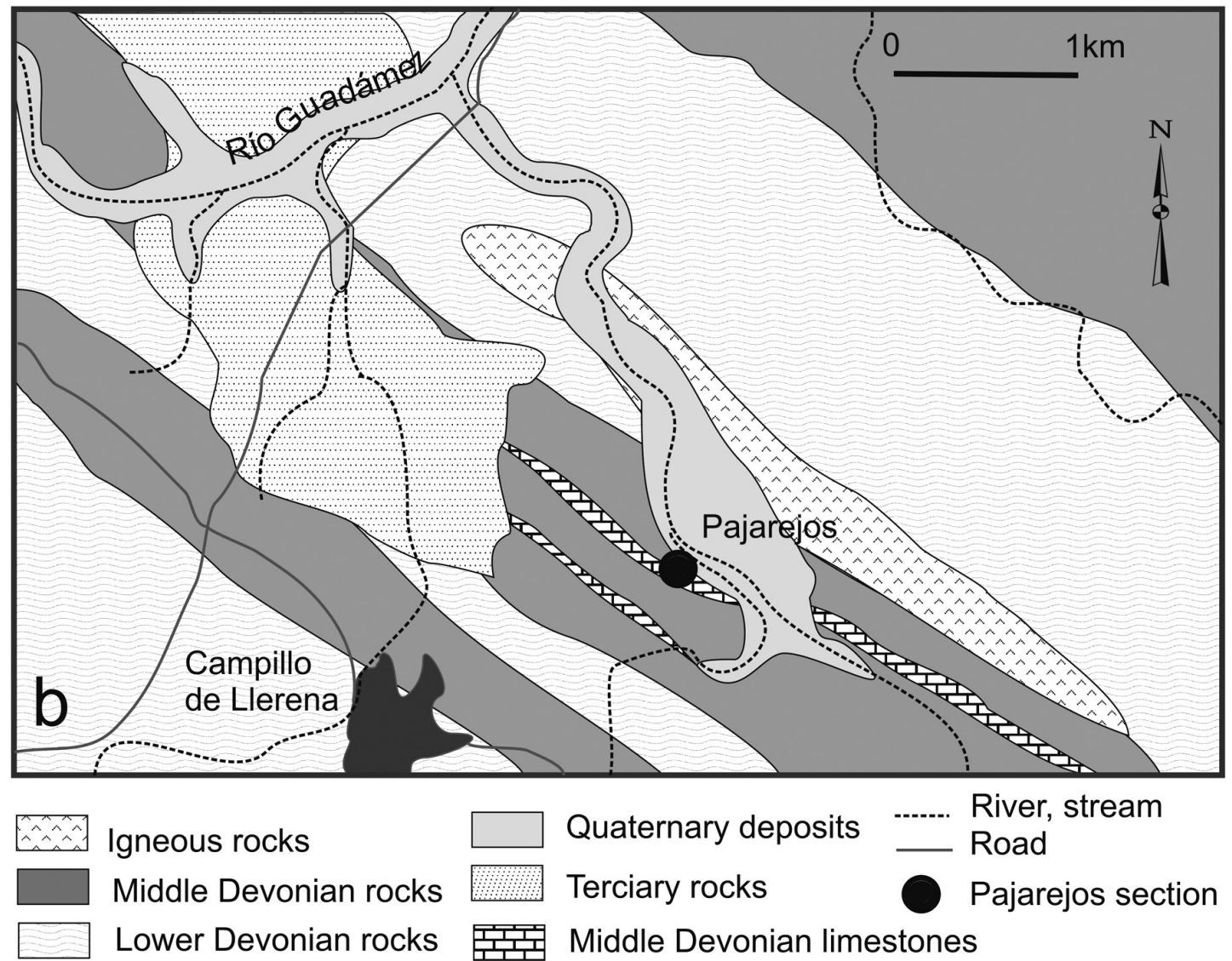

Figure 1. Geographical position of the studied area. a, Location of outcrops in the Iberian Penninsula. b, Geological sketch with location of outcrops near Campillo de Llerena. 
are common in the upper 12.5 metres as fragments and as nuclei of ooids and oncoids, embedded in sparite matrix. No microfossils other than some filaments of Girvanella Nicholson \& Etheridge, 1878 that occur in the oncoids have been identified in thin sections. The main aim of this paper is an overview of the bryozoan fauna from the Pajarejos outcrops and its implication for age determination and palaeobiogeographic comparison.

\section{MATERIAL AND METHODS}

The outcrops near Pajarejos were visited and sampled in November 2007. From a few samples 12 randomly oriented thin sections were made. These thin sections were studied with a transmitted light binocular microscope. The

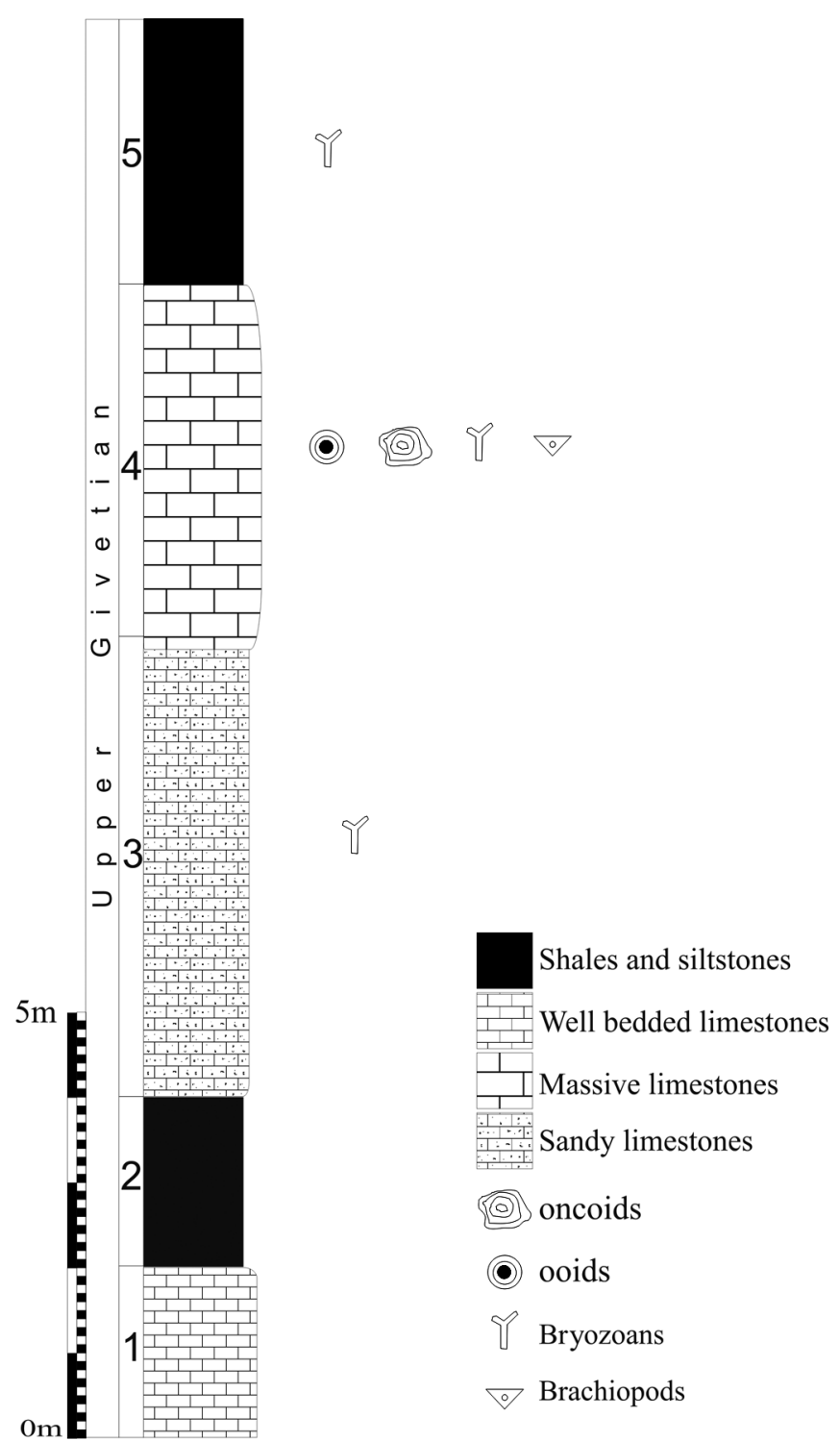

Figure 2. Stratigraphic chart of the studied outcrops showing the position of the bryozoan fauna. material is housed at the Senckenberg Museum (Frankfurt am Main, Germany), under collection numbers SMF 20.800-20.811.

\section{DISCUSSION}

The limestone from the studied locality represents a well-washed oolitic grainstone, with a clear sparitic matrix. Micrite is almost absent. The main components of this grainstone are ooliths with nuclei containing skeletal fragments of bryozoans and also unidentifiable echinoderms and ancillary brachiopods and gastropods (Fig. 3a). The ooliths have concentric layers developed in different stages around skeletal fragments (Fig. 3b). The fauna is strongly fragmented, the majority of fragments having diameters of $1 \mathrm{~mm}$.

Despite the small sizes of the skeletal fragments, bryozoans show good preservation and are suitable for taxonomic work. The following bryozoan species were identified in the studied thin sections:

Cyclotrypa cyclostoma (Schlüter, 1889) (Fig. 4a)

Sulcoretepora obliqua McNair, 1937

Acanthoclema triangularis Ernst \& Königshof, 2010.

(Fig. 4b-c)

Vidronovella fastigiata Gorjunova, 2006 (Fig. 4d)

Cryptostyloecia hexapuncta Ernst, Königshof \& Schäfer, 2009 (Fig. 4e-g)

Dissotrypa sincera Ernst \& Königshof, 2010 (Fig. 4h)

Hemitrypa sp.

Anastomopora recta Ernst \& Königshof, 2010

This association is also known from Middle Devonian rocks of the Sabkhat Lafayrina reef complex in the Tindouf Basin, Western Sahara (Ernst \& Königshof, 2008, 2010; Ernst et al., 2009). The bryozoan fauna from Sabkhat Lafayrina includes 27 species, with 17 new species, known previously only from the type locality. All the eight species identified in the oolitic limestone at Pajarejos occur also in the Sabkhat Lafayrina reef complex, from them Acanthoclema triangularis, Cryptostyloecia hexapuncta, Dissotrypa sincera, and Anastomopora recta are known exclusively from the North African locality. Cyclotrypa cyclostoma was previously described from the Middle Devonian (Eifelian-Givetian) of the Rhenish Massif (Ernst, 2008), and also from the Eifelian of the Holy Cross Mountains (Kiepura, 1973). Sulcoretepora obliqua was originally described from the Traverse Group (Middle Devonian, Givetian) of Michigan, USA, and later recorded from the Middle Devonian (Givetian) of the Rhenish Massif (Ernst, 2008). Vidronovella fastigiata was originally known from the Late Devonian (Famennian) of Afghanistan, but is a ubiquitous species in the Sabkhat Lafayrina reef complex in Western Sahara.

The generic composition of the Sabkhat Lafayrina reef complex shows relations to the Middle Devonian 

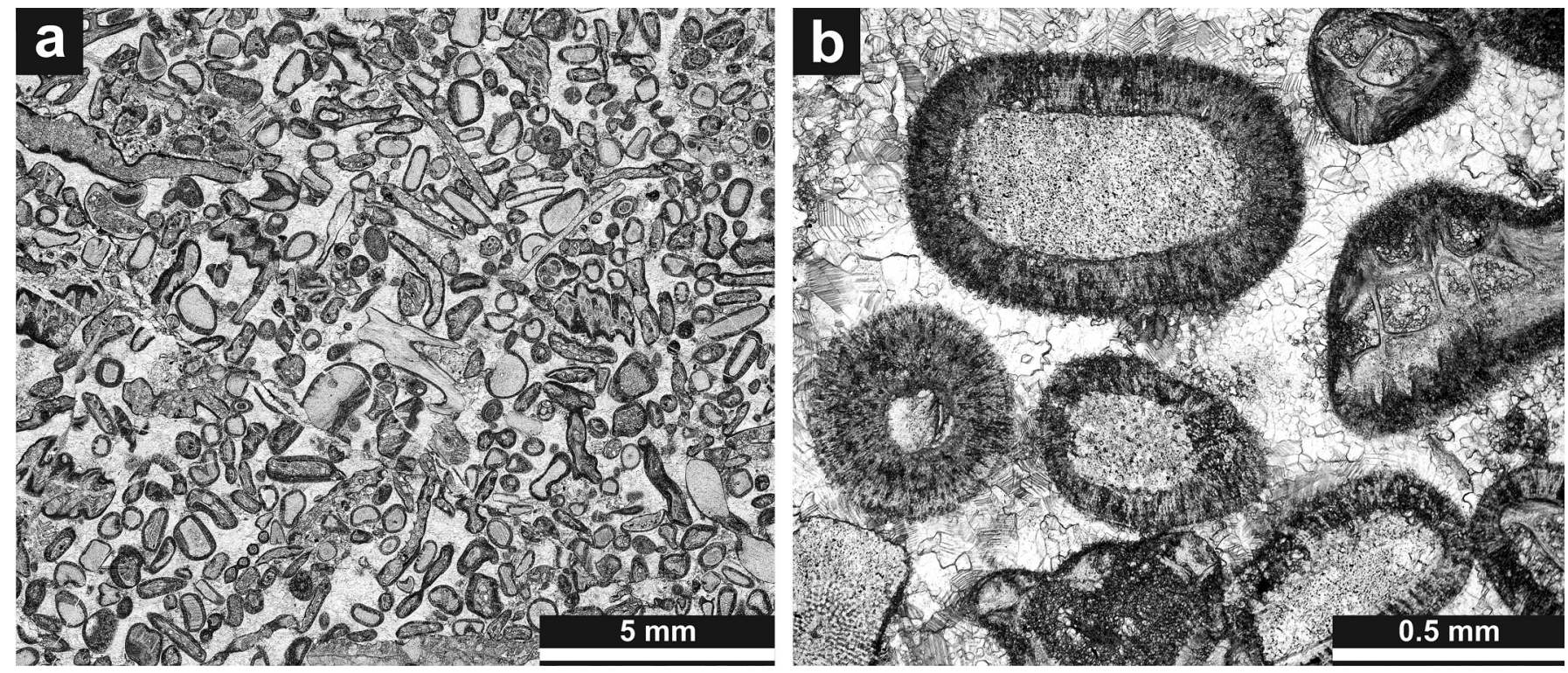

Figure 3. Oolitic limestone microfacies (SMF 20.811). a, General view of oolitic limestone. b, Detail showing ooids nucleate mainly in echinoderm plates and bryozoans.

of North America and Europe (Rhenish Massif). The age of the fauna from Sabkhat Lafayrina is estimated to be Late Givetian (Ernst \& Königshof, 2010). We conclude, therefore, that the bryozoan assemblage from the oolitic limestone indicates most probably Givetian age of the studied section. The closest palaeobiogeographic connection of the studied fauna is to Sabkhat Lafayrina in Western Sahara, which is situated more than 1,000 km further southward today. Secondarily, this fauna shows connections to the Middle Devonian of Middle Europe and the Traverse Group of Michigan. These connections are based on species which have wide distributions inside the Rheic Ocean (Cyclotrypa cyclostoma, Sulcoretepora obliqua), and are also present in the Sabkhat Lafayrina reef complex in Western Sahara.

The position of Iberia during the Middle Devonian is not well defined. The majority of authors reconstruct the linking of Southwest Europe to the Old Red Continent (Ziegler, 1988; Scotese \& McKerrow, 1990; Cocks \& Scotese, 1991; McKerrow et al., 1991; Soper et al., 1992). In contrast, some other authors reconstruct Southwest Europe at the NW margin of Gondwana, facing North Africa, and separate it from northern Europe by a rather wide Rheic ocean (Robardet et al., 1990; Paris \& Robardet, 1990; Li et al., 1993). The very close link between the two localities (Sabkhat Lafayrina and Pajarejos) based on bryozoan assemblages supports the reconstruction of South-western Spain positioned at the margin of Gondwana. The area of North Africa and Southern Spain had an intermediate position between the Appalachian Province and the European-Mediterranean Province (e.g., Stampfli et. al., 2002).

\section{CONCLUSIONS}

The bryozoan assemblage from Pajarejos outcrop is composed of 8 species. This assemblage dates the outcrop as Late Givetian. All species from Pajarejos have been previously described from Sabkhat Lafayrina in Western Sahara. It indicates a close relationship between these outcrops. Consequently, it supports the location of the Ossa-Morena terraine in the Northern margin of Gondwana during the Middle Devonian.

\section{ACKNOWLEDGEMENTS}

We are thankful to Wolfgang Reimers, Kiel for his help in preparation of thin sections. Paul Taylor, London is greatly thanked for language correction and helpful comments to the manuscript. The present study was accomplished during the project ER 278/4-1 u. 2 supported by the Deutsche Forschungsgemeinschaft (DFG), project CGL2006-03085/BTE,

Figure 4. Bryozoans from Pajarejos, NE Campillo de Llerena, Spain. a: Cyclotrypa cyclostoma (Schlüter, 1889), tangential section, SMF 20.801; b-c: Acanthoclema triangularis Ernst \& Königshof, 2010., tangential section, SMF 20.802; d: Vidronovella fastigiata Gorjunova, 2006, branch oblique section, SMF 20.801; e-g: Cryptostyloecia hexapuncta Ernst, Königshof \& Schäfer, 2009, oblique (e-f) and transverse (g) sections, SMF 20.806; h: Dissotrypa sincera Ernst \& Königshof, 2010, tangential section, SMF 20.811. 


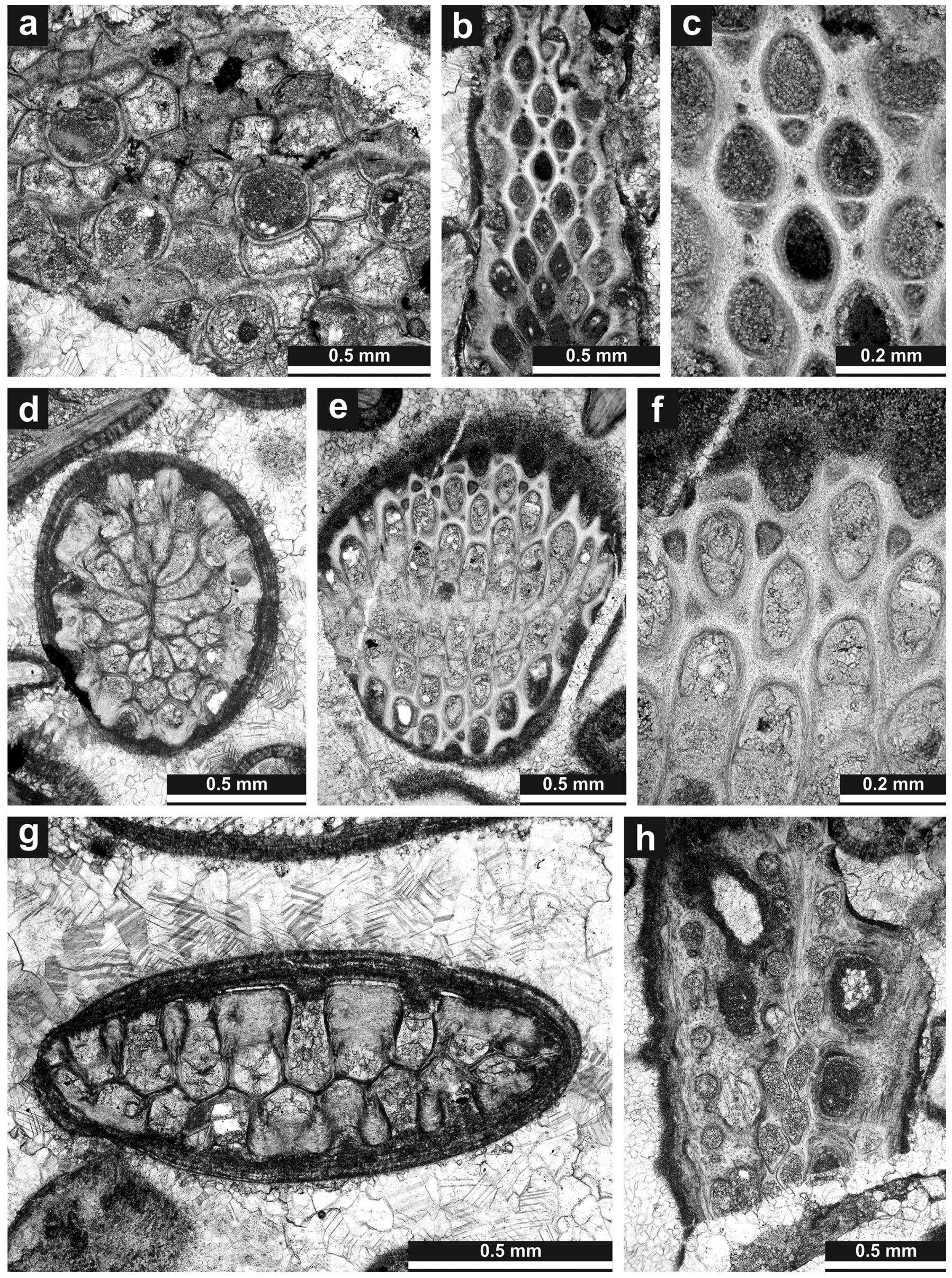


supported by the Spanish DGICYT and project UCM Research Group 910231, supported by BSCH and U.C.M. This paper is a contribution to IGCP 499 "Devonian land-sea interaction: evolution of ecosystems and climate".

\section{REFERENCES}

Cocks, L.R.M. \& Scotese, C.R. 1991. The global biogeography of the Silurian period. In: The Murchison Symposium (Proc. Intern. Confer. Silurian System, Keele, 1989) (eds. M.G. Basset, P.D. Lane, \& D. Edwards). Special Papers in Palaeontology, 44, 109-122.

Dallmeyer, R.D. \& Martínez-García, E. 1990. Introduction to The Pre-Mesozoic Geology of Iberia. In: Premesozoic Geology of Iberia (Eds. R. D. Dallmeyer \& E. Martínez García). Springer Verlag, Berlín, 3-4.

Ernst, A. 2008. Non-fenestrate bryozoans from the Middle Devonian of the Eifel (western Rhenish Massif, Germany). Neues Jahrbuch für Geologie und Paläontologie, Abhandlungen, 250, 313-379.

Ernst, A. \& Königshof, P. 2008. The role of bryozoans in fossil reefs - an example from the Middle Devonian of the Western Sahara. Facies, 54, 613-620.

Ernst, A. \& Königshof, P. 2010. Bryozoan fauna and microfacies from a Middle Devonian reef complex (Western Sahara, Morocco). Abhandlungen der Senckenberg Gesellschaft für Naturforschung, 568, 1-91.

Ernst, A., Königshof, P. \& Schäfer, P. 2009. Unusual skeletal morphology and systematic description of a new Devonian cryptostome bryozoan from the Western Sahara. Paläontologische Zeitschrift, 83, 449-457.

Gorjunova, R.V. 2006. New bryozoans from the Devonian of Afghanistan and the Carboniferous of Iran. Paleontologicheskii Zhurnal, 2006 (6), 43-51 [in Russian].

Julivert, M., Fontboté, J.M., Ribero, A. \& Conde, L.N. 1974. Memoria del mapa tectónico de la Península Ibérica y Baleares a escala 1:1.000.000. IGME, Madrid, 1-27.

Kiepura, M. 1973. Devonian Bryozoa of the Holy Cross Mountains, Poland. Part II. Cyclostomata. Acta Palaeontologica Polonica, 18, 323-400.

Li, Z.-X., Powell, C. Mc A. \& Trench, A. 1993. Palaeozoic global reconstruction. In: Palaeozoic Vertebrate Biostratigraphy and Biogeography (ed. J.A. Long). Bethaven Press, London, 25-53.

McKerrow, W.S., Dewey, J.F. \& Scotese, C.R. 1991. The Ordovician and Silurian development of the Iapetus Ocean. In: The Murchison Symposium (Proc. Intern. Confer. Silurian System, Keele, 1989) (eds. M.G. Basset, P.D. Lane \& D. Edwards) Special Papers in Palaeontology, 44, 165-178.

McNair A.H. 1937. Cryptostomatous Bryozoa from the Middle Devonian Traverse Group of Michigan. Contributions from the Museum of Paleontology, University of Michigan, 5, 103-170.
Nicholson, H.A. \& Etheridge, R. 1878. A monograph of the Silurian fossils of the Girvan District in Ayrshire with special reference to those contained in the 'Gray collection', I, volume 1. Blackwood, Edinburgh, $341 \mathrm{pp}$.

Paris, F. \& Robardet, M. 1990. Early Palaeozoic palaeobiogeography of the Variscan regions. In: Terranes in the Variscan belt of Europe and Circum-Atlantic Paleozoic Orogens (IGCP Project 233, Montpellier, 1988) (ed. P. Matte). Tectonophysics, 177, 193-213.

Quesada, C. 2006. The Ossa-Morena Zone of the Iberian massif: a tectonostratigraphic approach to its evolution. Zeitschrift der Deutschen Geologischen Gesellschaft, 157, 585-595.

Ribeiro, A., Munhaa, J., Dias, R., Mateus, A., Pereira, E., Ribeiro, L., Fonseca, P., Araujo, A., Oliveira, T., Romao, J., Chamine, H., Coke, C. \& Pedro, J. 2007. Geodynamic evolution of the SW Europe Variscides. Tectonics, 28 (6), 1-24.

Robardet, M., Paris, F. \& Racheboeuf, P.R. 1990. Palaeogeographic evolution of southwestern Europe during Early Palaeozoic times. In: Palaeozoic Palaeogeography and Biogeography (Symposium Oxford, 1988) (eds. W.S. McKerrow, C.R. Scotese), Geological Society of London Memoir, 12, 411-419.

Rodríguez, S. 1978. Corales rugosos del Devónico y Carbonifero de la Sierra del Pedroso. Tesis de Licenciatura Universidad Complutense de Madrid (Unpublished), 1- 144.

Sánchez-Cela, V. \& Gabaldón, V. 1977. Memoria y mapa geológico de España 1:50.000, Zalamea de la Serena. 831. IGME, Madrid, 1-28.

Scotese, C.R. \& McKerrow, W.S. 1990. Revised World maps and introduction. In: Palaeozoic Palaeogeography and Biogeography (Symposium Oxford, 1988) (eds. W.S. McKerrow, W.S. \& C.R. Scotese). Geological Society of London Memoir, 12, 1-21.

Schlüter, C. 1889. Anthozoen des rheinischen Mittel-Devon. Abhandlungen zur geologischen Specialkarte von Preussen und den Thüringischen Staaten, 8 (4), I-X, 259-465.

Soper, N.J., Strachan, R.A., Holdsworth, R.E., Gayer, R.A. \& Greiling, R.O. 1992 - Sinistral transpression and the Silurian closure of Iapetus. Journal of the Geological Society of London, 149, 871-880.

Stampfli, G.M., Raumer, von J.F. \& Borel, G.D. 2002. Paleozoic evolution of pre-Variscan terranes: From Gondwana to the Variscan collision. Geological Society of America, Special Paper, 364, 263-280.

Ziegler, P.A. 1988. Laurussia - the Old Red Continent. In: Devonian of the World (Proceedings of the 2nd International Symposium on the Devonian System, Calgary, 1987). (eds. N.J. McMillan, A.F. Embry \& D.J. Glass). Canadian Society of Petroleum Geologists, Memoir, 14, 15-48.

Manuscrito recibido: 23 de Diciembre, 2009 Manuscrito aceptado: 21 de Junio, 2010 